\title{
Analisis Pengaruh Work from Home, Digital Platform dan Aplikasi Rapat Online terhadap Produktivitas Kerja pada PT. Telkom Akses di Jakarta Barat (Analyzing the Effect of Work from Home, Digital Platform and Online Meeting Applications on Work Productivity at PT. Telkom Access in West Jakarta)
}

Dwi Hafifah Perdiyanti ${ }^{1 *}$, Dewi Puspaningtyas Faeni ${ }^{2}$

Fakultas Ekonomi dan Bisnis, Universitas Budi Luhur, Jakarta Selatan ${ }^{1,2}$

dwihafifah98@gmail.com ${ }^{1 *}$,dfaeni@yahoo.com ${ }^{2}$

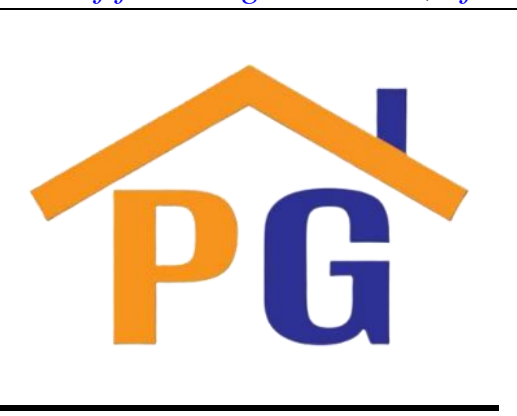

Riwayat Artikel

Diterima pada 20 Oktober 2020

Direvisi pada 1 April 2021

Disetujui pada 21 Juni 2021

\begin{abstract}
Purpose: This research aimed to analyze the impact of Work from Home, Digital Platform, and Online Meeting Applications on Work Productivity. This research aimed to observe the correlation of the three factors of exogenous variables towards work productivity.
\end{abstract}

Research Methodology: Sampling in this study used Random Sampling Techniques by spreading questionnaires to PT Telkom Access - West Jakarta towards 100 people. It shows that the population of PT Telkom Access - West Jakarta are 984 people. The methodology used to collect data was with the distribution of questionnaires. The statistical test tool utilized was SmartPLS 3.0.

Results: Based on the results, the study shows that Work from Home positively affects work productivity, the Digital Platform positively affects work productivity, and the Online Meeting Applications positively affects Work Productivity.

Keywords: Work from Home, Digital Platform, Online Meeting Applications, Work Productivity

How to cite: Perdiyanti, DH., \& Faeni, D. P. (2021). Analisis Pengaruh Work from Home, Digital Platform dan Aplikasi Rapat Online terhadap Produktivitas Kerja pada PT. Telkom Akses di Jakarta Barat. Studi Akuntansi, Keuangan, dan Manajemen, 1(1), $9-16$.

\section{Pendahuluan}

Indonesia adalah negara besar, bukan hanya jumlah penduduknya tapi juga sumber daya yang melimpah dan terbesar dipelosok Tanah Air, bahkan dunia, sedang dalam kondisi pandemic yaitu Covid-19 yang tentunya mempengaruhi aktivitas seluruh masyarakat dunia dan bagi tenaga kerja diIndonesia sehingga perusahaan pun harus menerapkan WFH. Penyebaran virus Covid-19 di Indonesia telat mencapai 1677 kasus positif. Dari jumlah tersebut korban meninggal dunia mencapai 157 orang dan jumlah yang sembuh 103 orang (CNN Indonesia, 01 April 2020) kurang lebih, Setiap Negara di dunia mengeluarkan kebijakan sebagai respon melawan dan menghentikan penyebaran virus Covid-19.

Untuk dapat mengimplementasikan WFH secara efektif, karyawan sendiri juga bisa untuk menciptakan sistem bekerja dirumah seperti memiliki ruang untuk bekerja dirumah atau untuk membuat suasana kerja yang aman dan nyaman. Tentunya menjadikan rumah sebagai tempat kerjanya atau disebut Home Office. Tetapi mengubah sistem kerja seperti dikantor beralih kerumah tidak lah mudah. Pada saat ini rumah yang dijadikan tempat kerja tentunya berpengaruh terhadap produktivitas kerja karyawan tersebut. Bekerja dari rumah adalah upaya pemerintah agar produktivitas tetap berjalan Sedangkan bagi perusahaan, Kebijakan tersebut dinilai menjadi upaya bersama dan sebagai kontribusi perusahaan dalam rangka menekan kemungkinan risiko menularnya virus corona. 
Platform adalah kumpulan teknologi yang menjadi basis aplikasi, proses atau teknologi lain untuk beroperasi dan dikembangkan. Diera digital saat ini, kemudahan, kenyamanan dan keamanan akses terhadap data dan aplikasi perusahaan sangatlah dibutuhkan guna mendukung produktivitas, terlebih bagi pekerja. Kumpulan teknologi ini menyediakan tempat untuk penggunanya berkomunikasi, berinteraksi, dan berinteroperasi dalam sebuah ekosistem. Perusahaan menggunakan berbagai macam perangkat kerja online dalam satu aplikasi agar produktivitas terus terjaga, akses terhadap data dan aplikasi harus bisa dilakukan kapan saja, dimana saja dan melalui perangkat apa saja. Saat ini digital platform bagi karyawan yang bekerja dirumah menggunakan salah satu aplikasi yang disebut Aplikasi Rapat Online. Aplikasi Rapat Online merupakan layanan konferensi video berbasiskan cloud computing. Aplikasi Rapat Online merupakan sebuah aplikasi yang dapat melakukan konferensi jarak jauh dengan menggabungkan konferensi video yang ada, salah satunya dengan memakai Aplikasi Rapat Online. Aplikasi ini membuat telecomuting jarang jauh lebih praktis efisien dan disertai banyak fitur-fitur yang membuat pertemuan online lebih nyaman. Video conference digunakan untuk monitoring, rapat mingguan, rapat bulanan, dan komunikasi.

Salah satu faktor yang mempengaruhi tingkat keberhasilan suatu perusahaan atau organisasi adalah produktivitas kerja karyawannya. Produktivitas kerja karyawan dalam melaksanakan tugasnya sesuai dengan tanggung jawab yang diberikan kepadanya. Menurut Helmiatin (2015) peran modal intelektual sangat berpengaruh terhadap produktivitas kerja karyawan dan dalam jangka panjang akan mempengaruhi kinerja organisasi, karena modal intelektual dapat digunakan organisasi untuk menciptakan kinerja yang diharapkan, dan sebagai alat evaluasi produktivitas kerja karyawan untuk menciptakan karyawan yang survive terhadap kebutuhan organisasi kedepan. Berdasarkan uraian diatas dalam mengatasi kesenjangan yang terjadi di PT Telkom Akses di Jakarta Barat diperlukan penerapan Work from Home, Digital Platform dan Aplikasi Rapat Online untuk dapat meningkatkan Produktivitas Kerja. Dari penjelasan tersebut maka akan diambil judul "Work from Home, Digital Platform dan Aplikasi Rapat Online terhadap Produktivitas Kerja Karyawan (Studi Kasus Pada PT Telkom Akses di Jakarta Barat).

\section{Kajian Teori}

\subsection{Pengertian Work from Home}

Work from Home konsep dimana karyawan dapat melakukan pekerjaannya dari rumah. Work from Home adalah suatu istilah bekerja dari jarak jauh, lebih tepatnya bekerja dari rumah. Jadi pekerja tidak perlu datang kekantor tatap muka dengan para pekerja lainnya. Work from Home ini sudah tidak asing bagi para pekerja freelancer, namun mereka lebih sering menyebutnya dengan kerja remote atau remote working. Bekerja dari rumah akan memebrikan waktu yang flaksibel bagi pekerja untuk memberikan keseimbangan hidup bagi karyawan. Disisi lain juga memberikan keuntungan bagi perusahaan. Biaya oprasional karyawan dengan kebijakan bekerja dirumah menjadi rendah namun biaya lain-lain seperti konsumsi bertambah (Rasid 2017).

\subsection{Pengertian Digital platform}

Platform suatu tempat yang dipergunakan untuk menjalankan perangkat sistem secara lunak. Dengan arti makna platform memberikan berbagai dampak yang baik, sehingga pelengkap seseorang dalam mejalankan sistemasiasi perangkatnya (Andika, 2015)

\subsection{Pengertian Aplikasi Rapat Online}

Aplikasi Rapat Online adalah fitur layanan konferensi video berbasis kolaborasi yang berbasis cloud termaksud pertemuan online, group layanan pengiriman pesan dan perekaman sesi yang aman (Aplikasi Rapat Online video communications Inc., 2016). Aplikasi Rapat Online merupakan aplikasi komunikasi dengan secara real time dengan individu yang tersebar secara geografis melalui komputer, tablet atau perangkat seluler. Pada umumnya para pengguna menggunakan aplikasi ini untuk melakukan meeting hingga konferansi video dan audio. 


\subsection{Pengertian Produktivitas Kerja}

Produktivitas secara umum dikatakan perbandingan antara hasil yang dapat dicapai dengan keseluruhan daya atau faktor produksi yang dipergunakan (Mangkunegara \& Prabu, 2003)

\subsection{Kerangka Teoritis}

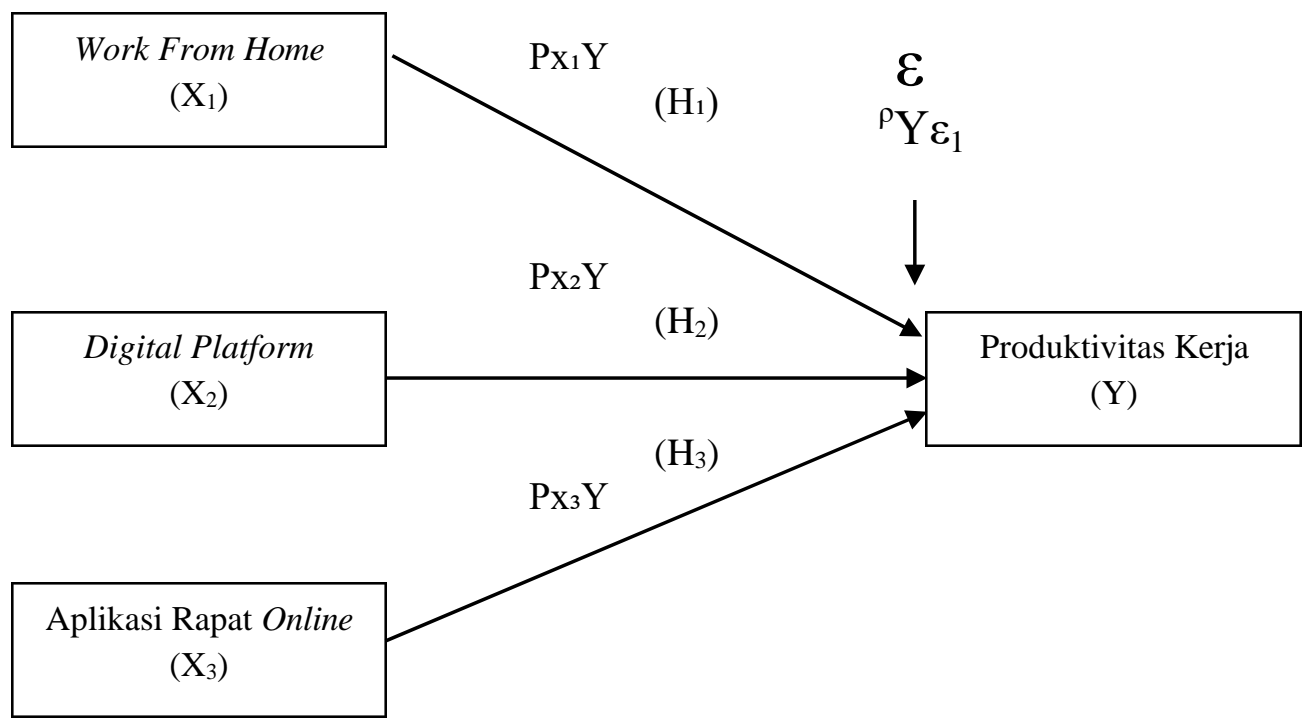

Gambar 1. Kerangka Teoritis

Sumber: Data Primer, 2020

\subsection{Hipotesis Penelitian}

Dalam melakukan penelitian, penulis merumuskan hipotesis penelitian karna penelitian ini menggunakan pendekatan kuantitatif. Hipotesis didapat dari diatas adalah sebagai berikut: $\mathrm{H}_{1}$ : Work form home $\left(\mathrm{X}_{1}\right)$ Berpengaruh Terhadap Produktivitas Kerja (Y) $\mathrm{H}_{2}$ : Digital Platform $\left(\mathrm{X}_{2}\right)$ Berpengaruh Terhadap Produktivitas Kerja (Y)

$$
\mathrm{H}_{3} \text { : Aplikasi Rapat Online }\left(\mathrm{X}_{3}\right) \text { Berpengaruh Terhadap Produktivitas Kerja (Y) }
$$

\section{Metodologi Penelitian}

Variabel dependen dalam penelitian ini adalah Produktivitas Kerja (Y) sedangkan variabel independen dalam penelitian ini adalah Work from Home $\left(\mathrm{X}_{1}\right)$, Digital Platform $\left(\mathrm{X}_{2}\right)$, Aplikasi Rapat Online $\left(\mathrm{X}_{3}\right)$. Untuk populasi dalam penelitian ini adalah karyawan PT. Telkom Jakarta Barat. Penelitian ini menggunakan teknik sampel simple random sampling. Populasi pada penelitian ini adalah karyawan PT Telkom Akses di Jakarta Barat. Waktu penelitian dilakukan dari bulan April sampai bulan Juni 2020. Pengumpulan pendapat responden dalam penelitian ini menggunakan kuesioner, maka penulis mengambil sempel sebanyak 100 karyawan PT. Telkom Akses Jakarta Barat yang tergolong sebagai data primer. Data yang berhasil terkumpul diolah dengan menggunakan program Microsoft Excel 2010 kemudian di uji menggunakan perangkat lunak program SmartPLS3.0 untuk mengetahui apakah data tersebut cukup layak untuk di analisi dan apakah hasil analisis data cukup mewakili keadaan yang sebenermya. Uji yang dimaksud terdiri dari uji validitas, uji reliabilitas, Hierarchial Component Model (HCM). Setelah itu, data yang lolos dalam uji tersebut selanjutnya dianalisis menggunakan uji kecocokan model (uji fit) diagram jalur penelitian, dan uji hipotesis.

\section{Pembahasan}

\subsection{Uji Validitas dan Reabilitas}

Pada uji validitas dan Reabilitas seluruh item pernyataan untuk variabel yang di uji memiliki nilai lebih besar 0,5. Sehingga dapat dikatakan bahwa item pernyataan untuk seluruh variabel adalah valid. Serta pada uji reabilitas dapat dilihat nilai Cronbach's Alpha dari masing-masing variabel memiliki nilai rata-rata $>0,7$ maka indikator pernyataan dari masing-masing variabel dapat dinyatakan reliabel dan dapat di terima. 
Tabel 1. Nilai Average Variance Extacted (AVE)

\begin{tabular}{|l|l|}
\hline Variabel/Konstruk & $\begin{array}{l}\text { Average Variance Extracted (AVE) } \\
(\mathbf{0}, \mathbf{5})\end{array}$ \\
\hline Work from Home (X1) & 0,617 \\
\hline Digital Platform (X2) & 0,589 \\
\hline Aplikasi Rapat Online (X3) & 0,591 \\
\hline Produktivitas Kerja (Y) & 0,651 \\
\hline & \\
\hline
\end{tabular}

Sumber: Output SmartPLS 3.0

Pada Tabel 1 dapat dilihat nilai AVE dari setiap variabel diatas 0,5 sehingga dapat dikatakan valid secara diskriminasi berdasarkan AVE.

Tabel 2. Hasil Penguji Reliabilitas Masing-masing Variabel

\begin{tabular}{|l|l|l|l|l|}
\hline \multirow{2}{*}{ Variabel } & \multicolumn{3}{c|}{ Hasil Pengujian } & \multirow{2}{*}{$\begin{array}{c}\text { Keterangan } \\
\text { Reliabilitas }\end{array}$} \\
\cline { 2 - 4 } $\begin{array}{l}\text { Work From } \\
\text { Home (X1) }\end{array}$ & 0,896 & 0,897 & 0,918 & \multirow{2}{*}{ Reliabel } \\
\cline { 2 - 5 } $\begin{array}{l}\text { Cronchbach's Alpha } \\
\text { (X2) }\end{array}$ & Rho_A & Composite Reliability & Reliabel \\
\hline $\begin{array}{l}\text { Aplikasi Rapat } \\
\text { Online (X3) }\end{array}$ & 0,901 & 0,829 & 0,877 & Reliabel \\
\hline $\begin{array}{l}\text { Produktivitas } \\
\text { Kerja (Y) }\end{array}$ & 0,819 & 0,904 & 0,920 & Reliabel \\
\hline
\end{tabular}

Sumber: Output SmartPLS 3.0

Berdasarkan pada Tabel 2 dapat terlihat bahwa nilai cronbach's alpha masing-masing variabel memiliki nilai lebih dari 0,7 dan composite reliability dari masing-masing variabel memiliki nilai lebih dari 0,5 sehingga dapat disimpulkan bahwa seluruh kosntruk dalam penelitian ini reliabel.

\subsection{Uji Hierarchical Component Model (HCM)}

Tabel 3. Hierarchical Component Model

\begin{tabular}{|c|c|c|c|}
\hline Variabel & Indikator & $\begin{array}{l}\text { Path } \\
\text { Coefficients }\end{array}$ & R Square \\
\hline \multirow{2}{*}{ Work form home $\left(\mathrm{X}_{1}\right)$} & 1. Individu & \multirow{2}{*}{0,552} & \multirow{11}{*}{0,951} \\
\hline & 2. Lingkungan & & \\
\hline \multirow{4}{*}{ Digital Platform $\left(\mathrm{X}_{2}\right)$} & 1. Interaktif & \multirow{4}{*}{0,196} & \\
\hline & 2. Hypertekstual & & \\
\hline & 3. Network & & \\
\hline & 4. Simulasi & & \\
\hline \multirow{5}{*}{$\begin{array}{l}\text { Aplikasi Rapat Online } \\
\left(\mathrm{X}_{3}\right)\end{array}$} & 1. Kemudahan & \multirow{5}{*}{0,247} & \\
\hline & 2. Kualitas video & & \\
\hline & 3. Vitur berbagi & & \\
\hline & 4. Keamanan & & \\
\hline & 5. Fleksibilitas & & \\
\hline
\end{tabular}


$\mathrm{R}$ Square atau disebut determinasi pada tabel hierarchical component model untuk mengetahui seberapa besar kontribusi variabel eksogen terhadap variabel endogen berdasarkan tabel 3 nilai $\mathrm{R}$ Square 0,951 atau 95,0\% Produktivitas Kerja dipengaruhi oleh Work from Home, Digital Platform, Aplikasi Rapat Online sedangkan sisanya sebesar 5\% dipengaruhi oleh faktor-faktor lain yang tidak termasuk dalam penelitian ini.

\subsection{Diagram Jalur Penelitian}

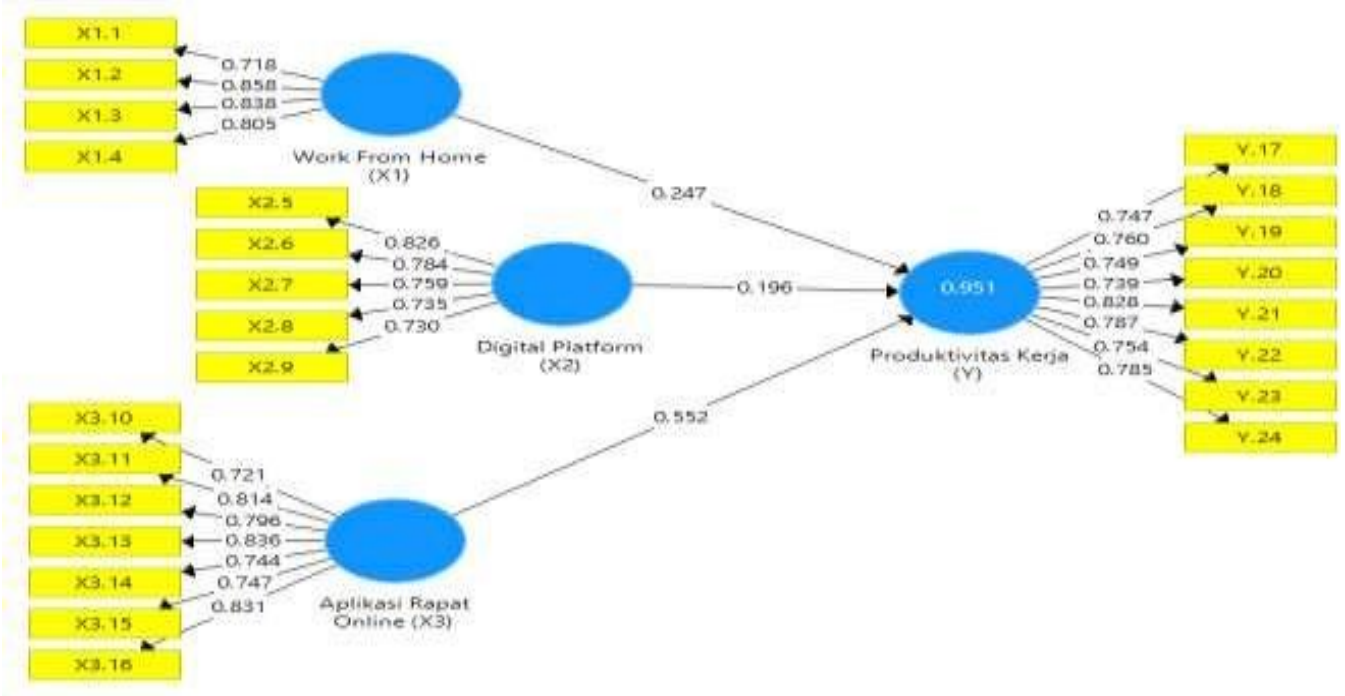

Gambar 2. Tampilan Output PLS Algorithme

Sumber: Output SmartPLS 3.0

4.4. Uji Kecocokan Model (Uji Fit)

Tabel 4. Hasil Uji Kecocokan Model

\begin{tabular}{|l|l|l|l|}
\hline $\begin{array}{l}\text { Model } \\
\text { Pengukuran }\end{array}$ & Kriteria & $\begin{array}{l}\text { Hasil } \\
\text { Pengujian }\end{array}$ & Keterangan \\
\hline SRMR & $<0.08$ (Henseler et. al, 2014) & 0,051 & Model Fit \\
\hline NFI & $>0.90$ (Lohmöller, 1989) & 0,931 & Model Fit \\
\hline rms Theta & $<0.12$ (Lohmöller, 1989) & 0,105 & Model Fit \\
\hline
\end{tabular}

Sumber: Output SmartPLS 3.0

Berdasarkan hasil pengujian pada Tabel 4 diketahui nilai SRMR, NFI dan rms Theta memenuhi kriteria yang ditetapkan, sehingga dapat berarti data yang dikumpulkan konsisten dan cocok dengan model menurut Goodness of Fit.

\subsection{Uji Hipotesis}

Tabel 5. Hasil Uji Signifikansi dari Indikator ke Variabel

\begin{tabular}{|l|l|l|l|l|}
\hline Variabel/Konstruk & Indikator & $\begin{array}{l}\text { T- } \\
\text { Statistic }\end{array}$ & $\begin{array}{l}\text { P- } \\
\text { Values }\end{array}$ & $\begin{array}{l}\text { Keterangan } \\
\text { Signifikansi }\end{array}$ \\
\hline \multirow{7}{*}{} & X1.1 Individu & 8,232 & 0,000 & Signifikan \\
\cline { 2 - 5 } & $\begin{array}{l}\text { X1.2 Lingkungan } \\
\text { Kerja }\end{array}$ & 25,295 & 0,000 & Signifikan \\
\hline
\end{tabular}




\begin{tabular}{|c|c|c|c|c|}
\hline Variabel/Konstruk & Indikator & $\begin{array}{l}\text { T- } \\
\text { Statistic }\end{array}$ & $\begin{array}{l}\text { P- } \\
\text { Values }\end{array}$ & $\begin{array}{l}\text { Keterangan } \\
\text { Signifikansi }\end{array}$ \\
\hline \multirow[t]{2}{*}{ Work from Home (X1) } & $\begin{array}{l}\text { X1.3 Lingkungan } \\
\text { Kerja }\end{array}$ & 17,566 & 0,000 & Signifikan \\
\hline & $\begin{array}{l}\text { X1.4 Lingkungan } \\
\text { Kerja }\end{array}$ & 19,243 & 0,000 & Signifikan \\
\hline \multirow{5}{*}{ Digital Platform (X2) } & X2.1 Interaktif & 17,508 & 0,000 & Signifikan \\
\hline & X2.2 Hypertekstual & 12,571 & 0,000 & Signifikan \\
\hline & X2.3 Network & 14,655 & 0,000 & Signifikan \\
\hline & X2.4 Network & 11,463 & 0,000 & Signifikan \\
\hline & X2.5 Simulasi & 10,616 & 0,000 & Signifikan \\
\hline \multirow{7}{*}{$\begin{array}{l}\text { Aplikasi Rapat Online } \\
\text { (X3) }\end{array}$} & X3.1 Kemudahan & 12,609 & 0,000 & Signifikan \\
\hline & X3.2 Kualitas Video & 17,011 & 0,000 & Signifikan \\
\hline & X3.3 Kualitas Video & 14,415 & 0,000 & Signifikan \\
\hline & X3.4 Fitur berbagi & 23,098 & 0,000 & Signifikan \\
\hline & X3.5 Fitur berbagi & 11,280 & 0,000 & Signifikan \\
\hline & X3.6 Keamanan & 10,250 & 0,000 & Signifikan \\
\hline & X3.7 Fleksibilitas & 22,224 & 0,000 & Signifikan \\
\hline \multirow{8}{*}{ Produktivitas Kerja (Y) } & Y.1 Kemampuan & 10,606 & 0,000 & Signifikan \\
\hline & $\begin{array}{l}\text { Y.2 Meningkatkan } \\
\text { hasil yang dicapai }\end{array}$ & 10,899 & 0,000 & Signifikan \\
\hline & $\begin{array}{l}\text { Y.3 Meningkatkan } \\
\text { hasil yang dicapai }\end{array}$ & 9,902 & 0,000 & Signifikan \\
\hline & Y.4 Semangat kerja & 14,667 & 0,000 & Signifikan \\
\hline & $\begin{array}{l}\text { Y.5 Semangat } \\
\text { bekerja }\end{array}$ & 18,280 & 0,000 & Signifikan \\
\hline & $\begin{array}{l}\text { Y.6 Semangat } \\
\text { bekerja }\end{array}$ & 14,204 & 0,000 & Signifikan \\
\hline & Y.7 Kualitas/mutu & 15,187 & 0,000 & Signifikan \\
\hline & Y.8 Efisiensi & 11,711 & 0,000 & Signifikan \\
\hline
\end{tabular}

Sumber: Output SmartPLS 3.0

\subsection{Variabel Work from Home $\left(X_{I}\right)$}

H0: $\rho Y X 1<0$ Work from Home tidak berpengaruh positif terhadap Produktivitas Kerja. H1: $\rho Y X 1>$ 0 Work from Home berpengaruh positf terhadap Produktivitas Kerja. Berdasarkan hasil pengolahan data diperoleh nilai koefisien jalur sebesar 0,552 dan p-value sebesar 0,001 (signifikan), artinya Work From Home berpengaruh signifikan dengan arah positif dan terhadap Produktivitas Kerja. 


\subsection{Variabel Digital Platform $\left(X_{2}\right)$}

H0: $\rho Y X 2<0$ Digital Platform tidak berpengaruh positif terhadap Produktivitas Kerja. H2: $\rho$ YX2 > 0 Digital Platform berpengaruh positif terhadap Produktivitas Kerja. Berdasarkan hasil pengolahan data diperoleh nilai koefisien jalur sebesar 0,196 dan p-value sebesar 0,031 (signifikan), artinya Digital Platform berpengaruh signifikan dengan arah positif dan terhadap Produktivitas Kerja.

\subsection{Variabel Aplikasi Rapat Online $\left(X_{3}\right)$}

H0: $\rho Y X 3<0$ Aplikasi Rapat Online tidak berpengaruh positif terhadap Produktivitas Kerja. H3: $\rho Y X 3>0$ Aplikasi Rapat Online berpengaruh positif terhadap Produktivitas Kerja. Berdasarkan hasil pengolahan data diperoleh nilai koefisien jalur sebesar 0,247 dan p-value sebesar 0,012 (signifikan), artinya Aplikasi Rapat Online berpengaruh signifikan dengan arah positif terhadap Produktivitas Kerja.

\section{Kesimpulan}

\subsection{Simpulan}

Berdasarkan pembahasan pada bab-bab sebelumnya, hasil analisis data dan pengujian-pengujian hipotesis secara parsial dapat disampaikan kesimpulan sebagai berikut: Variabel work from home mempunyai pengaruh positif dan signifikan terhadap produktivitas kerja pada karyawan PT Telkom Akses di Jakarta Barat. Variabel digital platform mempunyai pengaruh positif dan signifikan terhadap produktivitas kerja pada karyawan PT Telkom Akses di Jakarta Barat. Variabel aplikasi rapat online mempunyai pengaruh positif dan signifikan terhadap produktivitas kerja pada karyawan PT Telkom Akses di Jakarta Barat.

\subsection{Implikasi Manajerial}

Penelitian ini memberikan beberapa implikasi manajerial untuk PT. Telkom Akses Jakarta Barat agar dapat terus meningkatkan Produktivitas kerja. Dapat diketahui bahwa selama work from home karyawan perlu meningkatkan produktivitas kerja walaupun berada di luar lingkungan perusahaan. Ketika perusahaan memeberika kebijakan untuk bekerja dari rumah proses kerja harus berjalan seperti biasa, dalam kondisi seperti ini kordinasi tugas harus dilakukan dengan secara berstruktur. Dengan memanafaatkan digital platform yang menggunakan software Aplikasi Rapat Online, Menggunakan Aplikasi Rapat Online untuk karyawan dalam memenuhi kebutuhan untuk tetap efektif.

\subsection{Saran}

1. Perusahaan perlu menerapkan kebijakan yang lebih baik ketika work from home sedang berlangsung untuk meningkatkan produktivtas kerja karyawan di PT. Telkom Akses Jakarta Barat.

2. Dalam menggunakan Aplikasi Rapat Online untuk keperluan karyawan pada perusahaan PT. Telkom Akses, perusahaan juga harus memfasilitasi karyawannya seperti penambahan/memberi kuota internet agar bekerja tidak terhambat dan produktivitas karyawan pun tercapai

3. Karyawan harus memanfaatkan digital platform untuk mencari informasi secara efektif dan efisien serta penyampaian informasi juga harus cepat dan tepat pada sasaran untuk mengembangkan produktivitas kerja serta tetap menjalin hubungan baik antar rekan kerja dalam situasi pandemi saat ini. 


\section{Referensi}

Archibald, M. M., Ambagtsheer, R. C., Casey, M. G., \& Lawless, M. (2019). Using zoom videoconferencing for qualitative data collection: perceptions and experiences of researchers and participants. International Journal of Qualitative Methods, 18, 1609406919874596.

CNN Indonesia. (2020). Update Corona 1 April 2020, Jumlah Pasien Positif Terinfeksi Virus Corona (Covid- 19) di Indonesia. Diakses https://www.cnnindonesia.com/nasional/2020040111200020- 489026/update-corona-1-april-1677-kasus-157-meninggal-103-sembuh

Mangkunegara, A. P., \& Prabu, A. (2003). Perencanaan dan Pengembangan Sumber Daya Manusia. Bandung: Refika Aditama.

Rashid, H., Ridda, I., King, C., Begun, M., Tekin, H., Wood, J. G., \& Booy, R. (2015). Evidence Compendium and Advice on Social Distancing and Other Related Measures for Response to An Influenza Pandemic. Paediatric respiratory reviews, 16(2), 119-126.

Student, Indonesia. (2017). 3+ Pengertian Platform Menurut Para Ahli Lengkap Diakses dari https://www.indonesiastudents.com/pengertian-platform-menurut-para-ahli/ 